\title{
RELATIONSHIP BETWEEN SERUM VITAMIN D LEVEL AND RECURRENT APHTHOUS ULCER
}

\author{
Fatma F. Hussein ${ }^{*}$ Lama H. El-Marssafy ${ }^{* *}$, Hesham S. Sadek ${ }^{* * *}$ and Mashael Alqahtani*****
}

\begin{abstract}
Introduction: Recurrent aphthous ulcer (RAU) is the most prevalent oral lesion. It is most commonly characterized by recurrent attacks of regular, oval or round, solitary or painful multiple ulcers and classified into three clinical forms; minor, major, and herpetiform RAUs. Vitamin D is a fat-soluble secosteroid pleiotropic molecule. Lower vitamin D serum level has been found to be involved in the etiology of many diseases.
\end{abstract}

Objective: The aim of this study was to compare levels of serum vitamin D in patients having RAU with healthy subjects to determine if a relationship exists between vitamin D level and the severity of the disease.

Subjects and Methods: In this study, 70 patients having idiopathic MiRAU (Group I) and 70 healthy control subjects with matched age and sex (Group II) were included. RAU severity was represented by number of ulcers per attack and the frequency of recurrence. 25-hydroxyvitamin D $(25(\mathrm{OH}) \mathrm{D})$ measured by enzyme-linked immunosorbent assay (ELISA) technique as an indicator of vitamin D status. The serum vitamin D levels were compared between group I and group II and correlated with RAU severity.

Results: The mean level of 25(OH)D in MiRAU group was significantly lower than the control group $(\mathrm{p}<0.001)$. According to classification of vitamin D serum levels, severe deficiency and deficiency levels of $25(\mathrm{OH}) \mathrm{D}$ were more common in MiRAU group than in control group. Obvious gender difference with decreased serum $25(\mathrm{OH}) \mathrm{D}$ levels in females compared to males was found in both groups. Significant inverse correlation was observed between serum 25(OH)D levels and severity of RAU regarding the number of ulcers per attack and frequency of recurrence.

Conclusions: In this study, significant association has been observed between serum vitamin D deficiency and RAU. Moreover, the strong influence of low serum vitamin D level on the severity of the disease suggesting its role in the pathogenesis of RAU.

KEY WORDS: 25(OH)D, RAU, MiRAU, vitamin D.

* Lecturer, Department of Oral Medicine, Oral Diagnosis and Periodontology, Faculty of Dentistry, Minia University, Egypt. Affiliated as Assistant Professor in Collage of Dentistry, Umm- Al-Qura University, KSA.

** Assistant Professor of Oral Medicine, Oral Diagnosis and Periodontology, Department of Basic and Clinical Oral Sciences, Collage of Dentistry, Umm Al Qura University, KSA.

***Professor, Department of Oral Medicine, Oral Diagnosis and Periodontology, Faculty of Dentistry, Cairo University, Egypt. Affiliated as Professor in Collage of Dentistry, Umm- Al-Qura University, KSA.

**** Assistant Professor of Oral and Maxillofacial Pathology, Department of Basic and Clinical Oral Sciences, Collage of Dentistry, Umm Al Qura University, KSA. 


\section{INTRODUCTION}

Recurrent aphthous ulcer (RAU) is the most prevalent oral lesion after dental caries and periodontal diseases ${ }^{[1,2]}$. Approximately $20 \%$ of the general population is affected by RAU ${ }^{[3]}$. It is most commonly characterized by recurrent attacks of regular, oval or round, solitary or painful multiple ulcers with yellowish white fibrinopurulent pseudomembrane center having an erythematous border usually on non-keratinized oral mucosa. Involvement of the keratinized mucosa is less frequent ${ }^{[4-}$ ${ }^{6]}$. Generally, RAU is classified into three clinical forms; minor, major, and herpetiform RAUs. Minor ulcers are shallow ulcers and accounting for more than $85 \%$ of cases with a diameter less than $1 \mathrm{~cm}$. Major ulcers have a deep base and diameter more than $1 \mathrm{~cm}$ which last for weeks and heal with scar ${ }^{[1,7]}$. Herpetiform ulcers are rare type and appear as multiple, pinpoint ulcers with 1-2 mm diameter and exit in $5 \%$ to $10 \%$ of all cases ${ }^{[8]}$.

Unfortunately, the etiopathogenesis of RAU so far remains unclear but strongly involves activation of cell-mediated immune response [9]. Multiple potential trigger factors may be associated with the establishment of this disease, including: genetic predisposition, local trauma, psychological stress, food hypersensitivity, toxin exposure (nitrates in drinking water), hormonal defects (menstruation), alterations in the oral microbiome, smoking cessation, increased oxidative stress and immune disturbance $^{[1,12]}$. Almost, $20 \%$ of cases are related to vitamin and microelement deficiencies (e.g. iron, folic acid, vitamin B6 and B12). Also other deficiencies such as vitamin $\mathrm{D}$, zinc, or thiamine may be present ${ }^{[11]}$.

Vitamin D is a fat-soluble secosteroid pleiotropic molecule that is recognized as a prohormone. 1, 25 dihydroxyvitamin $\mathrm{D}(1,25(\mathrm{OH}) 2 \mathrm{D} 3)$ (calcitriol) is the functional active metabolite of Vitamin $\mathrm{D}^{[13,14]}$. The mode of action of the calcitriol is mediated by vitamin $\mathrm{D}$ receptor (VDR). VDR has been expressed in virtually all cell types ${ }^{[15]}$ including keratinocytes, ovarian cells and islet cells of the pancreas ${ }^{[16]}$. As well as most of immune cells, like monocytes, macrophages, $\mathrm{B}$ and $\mathrm{T}$ lymphocytes and dendritic cells and this may explain its multiple critical actions on different tissues ${ }^{[16,17]}$.

Functions of vitamin D are to regulate calciumphosphorus homeostasis, control of metabolism bone and play a role in the regulation of electrolytes and blood pressure ${ }^{[18]}$. Recently, after understanding the vitamin D/ VDR signalling pathway, it was shown that vitamin $\mathrm{D}$ has a non classical role in cellular differentiation, proliferation, and immune responsiveness ${ }^{[13,19]}$. Moreover, vitamin D enhances immunoregulation, neuroprotective functions, xenobiotic detoxification, anti-fibrotic actions [20], antimicrobial defense, oxidative stress reduction and possesses anti-inflammatory/anticancer activities and cardiovascular benefits ${ }^{[20-22]}$.

However, vitamin D deficiency has been linked to many musculoskeletal diseases (rickets in children and osteomalacia in adults, bone fractures, osteoporosis, osteopenia and muscle weakness).

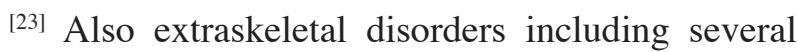
chronic conditions associated with increased inflammation and immune system deregulation such as cardiovascular diseases ${ }^{[24]}$, respiratory disorders, diabetes and asthma ${ }^{[25]}$. Furthermore, several studies revealed the key role of vitamin D deficiency in tuberculosis, autoimmune diseases, inflammatory bowel diseases, cancers ${ }^{[26]}$, common obesity ${ }^{[27]}$, schizophrenia ${ }^{[28]}$, depression, cognitive deficits ${ }^{[29]}$, cystic fibrosis ${ }^{[30]}$ and non-alcoholic fatty liver disease ${ }^{[31]}$. All of those bring to light that vitamin D play role in regulation of immune system.

Given the importance of vitamin D effect on the immune system and the possible role as immunologic factor in the etiology of many diseases, the present study was designed to compare serum vitamin D levels in patients having RAU with healthy subjects to determine if a relationship exists between vitamin $\mathrm{D}$ level and the severity of the disease. 


\section{SUBJECTS AND METHODS}

The study was carried out at outpatient clinic of Faculty of Dentistry, Umm Al-Qura University in Makkah. The current study was divided into two groups, group I include 70 patients with idiopathic minor recurrent aphthous ulcer (MiRAU) and group II include 70 healthy control subjects selected from the out-patient clinic.

\section{Patient selection}

\section{Inclusion criteria:}

- The selected patients were of both sexes with age ranging from 18-60 years.

- Patients with minimum 3 oral aphthous ulcers per year were diagnosed as having idiopathic MiRAU, after taking medical histories and clinical examinations and the participants signed informed consent forms.

- The severity of the disease was evaluated by the number of aphthae per attack $(3$ or $<3$ and $>3$ ) and by frequency of recurrences (type 1 : the intervals between the attacks of more than 3 months, type 2: the attack occur at one to 3 months intervals, while type 3 , aphthous lesions are continuously exist ${ }^{[32]}$ dependant on the patient's self-report.

- 70 healthy control subjects with matched age and sex were included with no history of RAU.

\section{Exclusion criteria:}

- History of taking any medications that alter the serum levels of vitamin D such as vitamin D supplements, multivitamin, calcium, calcium channel blockers and sun screen or sun blockers cream.

- Use of medications for the treatment of RAU in last three months.
- Use of corticosteroids, cytotoxic drugs, colchicine, disease modifying anti-rheumatic drugs (DMARDs) and anticonvulsant drugs or any drug affecting bone metabolism in the past six months.

- Patients with history of chronic disease such as renal or hepatic diseases, type 1 diabetes mellitus, malignancies, thyroid or parathyroid disease.

\section{Blood Sampling:}

A 5-mL blood sample was withdrawn in the outpatient clinic and collected in Vacutainer tubes. Blood taken from all subjects centrifuged for 15 min at $4{ }^{\circ} \mathrm{C}$ to separate serum. Serum immediately stored at $-20{ }^{\circ} \mathrm{C}$ until laboratory serum vitamin $\mathrm{D}$ levels were analyzed.

\section{Serum Vitamin D Levels Measurement:}

Total 25-hydroxyvitamin D (25(OH)D) levels were considered the most accurate marker for vitamin D [33]. 25(OH)D was measured by commercially available enzyme-linked immunosorbent essay (ELISA) kits*. Regarding to the serum 25(OH) D level each sample was classified as normal (30-100 $\mathrm{ng} / \mathrm{ml}$ ), insufficient (20-30 ng/ml), deficient (10$20 \mathrm{ng} / \mathrm{ml})$, severe deficient $(<10 \mathrm{ng} / \mathrm{ml}))$ or toxic $(>100 \mathrm{ng} / \mathrm{ml})^{[34]}$.

\section{Statistical Analysis:}

Data from140 subjects were recorded on spreadsheet of excel and statistically analyzed using "Statistical Package for Social Sciences" "SPSS" v. 19.0 for Windows Software Package (SPSS Inc., Chicago, IL, USA). Descriptive data expressed as mean \pm standard deviations (SD) and range (Min., Max.). Analytical data in the form of the student's test, paired t test, analysis of variance (ANOVA), 
correlation matrix and coefficient of correlation using Pearson's method were performed. The probability value of $\mathrm{p}<0.05$ was considered significant.

\section{RESULTS}

Clinical parameters of group I and group II: Table (1)

Group I with a total number of $70 \mathrm{Mi}$ RAU patients, 39 female $(55.71 \%)$ and 31 male (44.29\%) and group II consists of 70 healthy controls 33 female (47.14\%) and 37 male (52.86\%) were all enrolled in this study. The mean age of patients in group I was 29.2571 \pm 10.7335 and mean age of participants in group II was $32.5857 \pm 10.3985$. No statistically significant difference detected regarding age between both groups.

The mean level of $25(\mathrm{OH}) \mathrm{D}$ was $20.2557 \pm$ $6.0174 \mathrm{ng} / \mathrm{ml}$ in group I while it was $29.9228 \pm$
$6.8048 \mathrm{ng} / \mathrm{ml}$ in group II. A statistically significant difference exists between both groups with p-value $<0.001$.

\section{Vitamin D serum level: Table (2) Graph (1)}

According to classification of vitamin D serum levels, a higher percentage of normal level of $25(\mathrm{OH})$ D existed in group II (45.71\%) when compared with group I (7.14\%). On the other hand, deficiency level was $(51.43 \%)$ in group I and $(8.57 \%)$ in group II and severe deficiency level was (5.71\%) in group I and $(0 \%)$ in group II. Both deficiency and severe deficiency level were more common in MiRAU patients than in control group.

\section{Clinical Parameters between Female and Male:} Table $(3 \& 4)$

By evaluating mean serum levels of $25(\mathrm{OH}) \mathrm{D}$ in female $(18.674 \pm 6.2499)$ or in male $(22.245 \pm 5.1442)$ at group I, and female (27.522 \pm 6.2345$)$ and male $(32.403 \pm 6.636)$ at group II, a significant difference

TABLE (1) Clinical Parameters of Group I and Group II

\begin{tabular}{|c|c|c|c|c|c|c|c|}
\hline \multirow[b]{2}{*}{ Parameter } & \multicolumn{3}{|c|}{ Group 1} & \multicolumn{3}{|c|}{ Group 2} & \multirow[t]{2}{*}{ P-Value } \\
\hline & Max & Min & Mean \pm SD & Max & Min & Mean \pm SD & \\
\hline Age & 60 & 18 & $29.2571 \pm 10.7335$ & 60 & 19 & $32.5857 \pm 10.3985$ & 0.06452 \\
\hline 25(OH)D level ng/ml & 38.2 & 5.3 & $20.2557 \pm 6.0174$ & 47.2 & 16.6 & $29.9228 \pm 6.8048$ & 0.00001 \\
\hline No. of ulcers/ attack & 4 & 1 & $1.4285 \pm 0.7336$ & ---- & ---- & ---- & \\
\hline Frequency (attacks/ year) & 24 & 3 & $4.8571 \pm 3.9609$ & ---- & ---- & ---- & \\
\hline
\end{tabular}

TABLE (2) Distribution of 25(OH) D serum level in Group I and Group II

\begin{tabular}{|c|c|c|c|c|}
\hline & \multicolumn{2}{|c|}{ Group I } & \multicolumn{2}{c|}{ Group II } \\
\hline $\mathbf{2 5}(\mathbf{O H}) \mathbf{D}$ level ng/ml & Number & percentage & Number & percentage \\
\hline Severe deficiency $:<\mathbf{1 0}$ & 4 & $5.71 \%$ & 0 & $0.00 \%$ \\
\hline Deficiency $: \mathbf{1 0}-\mathbf{2 0}$ & 36 & $51.43 \%$ & 6 & $8.57 \%$ \\
\hline Insufficiency $: \mathbf{2 0}-\mathbf{3 0}$ & 25 & $35.71 \%$ & 32 & $45.71 \%$ \\
\hline Normal : 30- 100 & 5 & $7.14 \%$ & 32 & $45.71 \%$ \\
\hline Toxicity : > 100 & 0 & $0.00 \%$ & 0 & $0.00 \%$ \\
\hline
\end{tabular}




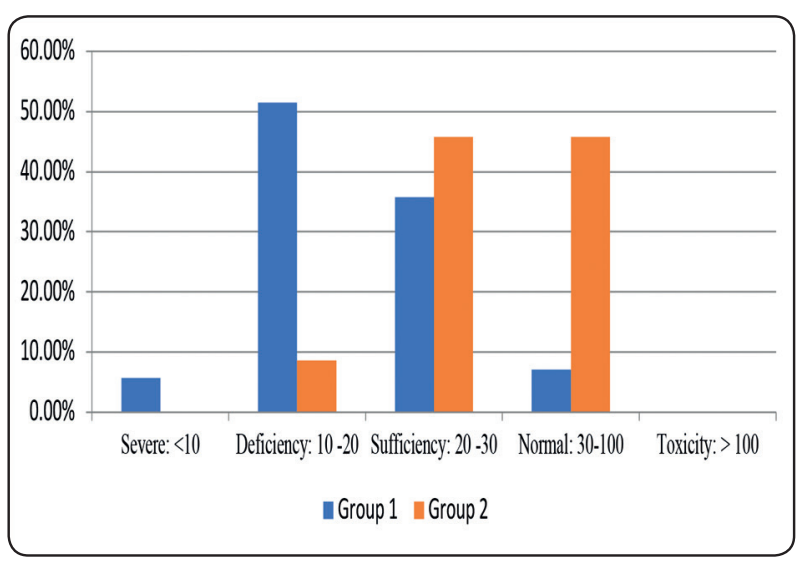

Graph (1) Showing sever deficiency and deficiency levels of serum $25(\mathrm{OH}) \mathrm{D}$ in MiRUA patients and in control group

exists between them in both groups. The lower serum level of $25(\mathrm{OH}) \mathrm{D}$ was found in female side when compared with male with $\mathrm{p}$-value $<0.001$ and $\mathrm{p}$-value $<0.05$ for group I and group II respectively. In regard to age, frequency and number of ulcers/ attack within group I there was no significant difference between female and male.

\section{Correlation between vitamin D serum level $\&$} severity of the lesion: Table (5) Graph ( $2 \& 3)$

In the MiRUA patients, the severity of the disease was determined by the number of aphthae per flare-up and by the frequency of recurrences. The number of cases who reported 3 or less than 3 ulcers per attack were 64 patients $(91.43 \%)$, while the remaining patients $(n=6,8.57 \%)$ reported more than 3 ulcers per attack. Concerning the frequency of recurrences, type 1 whose intervals between the attacks were more than 3 months, existed in $45.71 \%$ of patients and type 2 whose intervals of attack occur within one to 3 months appeared in $51.43 \%$ of patients, while type 3 which characterized by continuous existence of aphthous lesions was found in only $2.86 \%$ of all cases. The serum levels of $25(\mathrm{OH}) \mathrm{D}$ of group I were correlated to the severity of MiRUA, a highly significant inverse correlation was observed between serum $25(\mathrm{OH})$ D levels, number of ulcers/ attack and frequency of recurrences ( $p$-value $<0.001)$.

TABLE (3) Comparison of Different Clinical Parameters between Female and Male In Group I

\begin{tabular}{|c|c|c|c|c|c|c|c|}
\hline \multirow[t]{2}{*}{ Parameter } & \multicolumn{3}{|c|}{ Female } & \multicolumn{3}{|c|}{ Male } & \multirow[b]{2}{*}{ P-Value } \\
\hline & Max & Min & Mean \pm SD & Max & Min & Mean \pm SD & \\
\hline Age & 52 & 18 & $28.256 \pm 9.0632$ & 60 & 18 & $30.516 \pm 12.569$ & 0.385502 \\
\hline 25(OH)D level ng/ml & 32.2 & 5.3 & $18.674 \pm 6.2499$ & 38.2 & 15.1 & $22.245 \pm 5.1442$ & 0.012568 \\
\hline No. of ulcers/ attack & 4 & 1 & $1.538 \pm 0.7896$ & 4 & 1 & $1.2903 \pm 0.6425$ & 0.161415 \\
\hline Frequency (No. of attacks/ year) & 24 & 3 & $4.692 \pm 3.6284$ & 24 & 3 & $5.0645 \pm 4.3964$ & 0.699146 \\
\hline
\end{tabular}

TABLE (4) Comparison of Different Clinical Parameters between Female and Male In Group II

\begin{tabular}{|c|c|c|c|c|c|c|c|}
\hline \multirow[t]{2}{*}{ Parameter } & \multicolumn{3}{|c|}{ Female } & \multicolumn{3}{|c|}{ Male } & \multirow[b]{2}{*}{ P-Value } \\
\hline & Max & Min & Mean \pm SD & $\operatorname{Max}$ & Min & Mean \pm SD & \\
\hline Age & 55 & 19 & $31.483 \pm 9.2767$ & 60 & 19 & $29.225 \pm 7.7704$ & 0.915269417 \\
\hline 25(OH)D level & 39.9 & 16.6 & $27.522 \pm 6.2345$ & 47.2 & 19.6 & $32.403 \pm 6.636$ & 0.00141399 \\
\hline
\end{tabular}


TABLE (5) Correlation between 25(OH)D level and Severity of the Lesion

\begin{tabular}{|c|c|c|c|}
\hline & $\mathbf{R}$ & $\mathbf{R}^{\wedge} \mathbf{2}$ & P Value \\
\hline $\begin{array}{c}\text { No. of ulcers/ } \\
\text { attack }\end{array}$ & -0.56959 & 0.324432091 & 0.00001 \\
\hline $\begin{array}{c}\text { Frequency (No. } \\
\text { of attacks/ year) }\end{array}$ & -0.45436 & 0.206445846 & 0.00001 \\
\hline
\end{tabular}

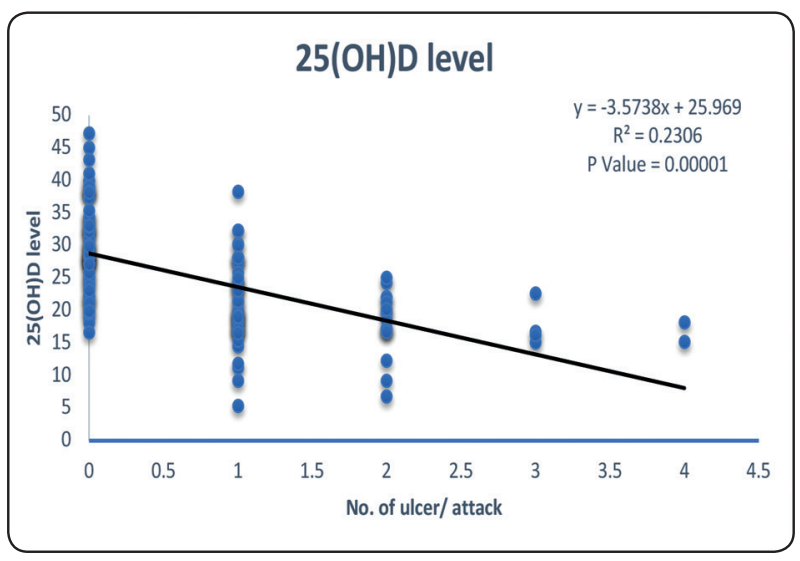

Graph (2) Showing significant correlation between serum $25(\mathrm{OH}) \mathrm{D}$ levels and number of ulcers/ attack

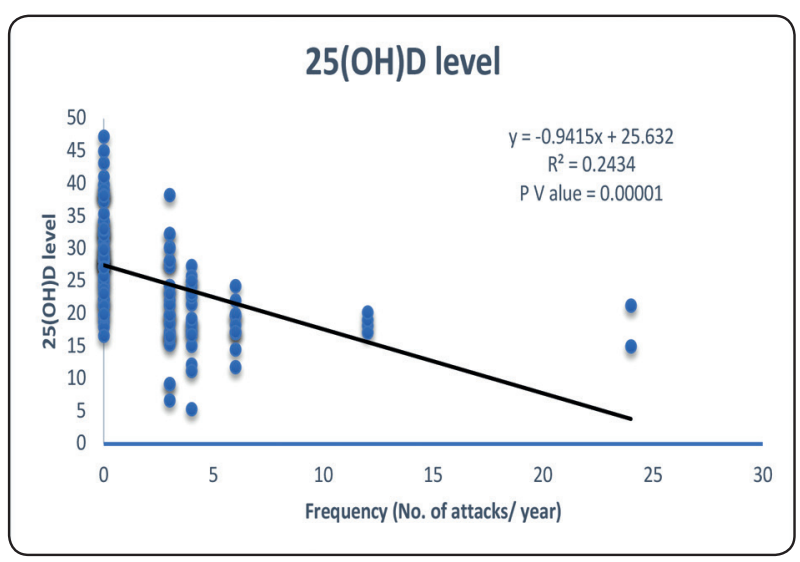

Graph (3) Showing significant correlation between serum $25(\mathrm{OH}) \mathrm{D}$ levels and number of frequency of recurrences

\section{DISCUSSION}

RAU is the most common oral painful condition that interfere eating, speaking, drinking and affect patient life quality. Recently, several studies have focused on identifying factors that may affect the treatment of RAU one of which is vitamin D level. For this reason, the current study was conducted to evaluate the levels of serum vitamin D in Mi RAU patients and healthy control subjects to investigate relationship between serum vitamin D levels and RAU.

The rational for choosing MiRAU in this study is because it is accounting $70-85 \%$ of RAUs ${ }^{[32]}$. Patients recruited in this study were selected with almost matched age and sex, which further confirmed by the lack of significant statistical difference in age between the two studied groups. The present study reported predominance of RAU in females $(55.71 \%)$. This result was in agreement with the results of Abdullah, 2013, Patil et al.,

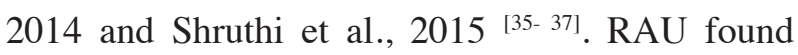
to be more prevelant in female due to hormonal level changes mainly related to fall in progesterone levels. The incidence of RAU increases during the luteal phase of the menstrual cycle, exacerbated during menopause and decreases during pregnancy [38, 39]. Other studies explained the higher incidence of RAU in females by the fact that women are more vulnerable to become anaemic ${ }^{[40]}$.

Comparatative statistical analysis of the two studied groups in this study registered significant reduction in mean serum level of $25(\mathrm{OH}) \mathrm{D}$ in RAU patients more than healthy controls ( $p$-value $<0.001$ ). Accordingly, the results of this study are in line with the research of Khabbazi et al., (2014), Bahramian et al., (2018), Oztekin and Oztekin, (2018) and Ali, (2019) ${ }^{[41,2,6,42]}$. Similarly, Nalbantog `lu and Nalbantoğlu, (2019) found significant difference related to vitamin $\mathrm{D}$ levels between children patients with recurrent aphthous ulcer and control group ${ }^{[43]}$. Moreover, in the study carried by Tamer and Avc1 
(2019) investigated the levels of serum ferritin and vitamin D in patients with RAU, they stated that in patients with RAU the level of serum vitamin D was also significantly lower than healthy individuals $(p=0.01)^{[44]}$. In contrast, Krawiecka et al (2017) reported lower vitamin D levels in RAU patients without statistically significant results $(p=0.207)$ but they also observed the lowest level of vitamin D in most severe form of RAU ${ }^{[45]}$.

It is interesting to note that in the present work, both studied groups showed significant lower serum $25(\mathrm{OH}) \mathrm{D}$ levels in females more than males. Our results were in agreement with the findings reported by Hagenau et al (2009) and Arabi et al (2010) ${ }^{[46,}$ 47]. In a cross sectional study done on 1172 Saudi Arabian women living in the Jeddah showed that $80 \%$ of participant had serum $25(\mathrm{OH}) \mathrm{D}$ levels $<50 \mathrm{nmol} / 1$ and $10 \%$ of them had severe deficiency with levels $<12.5 \mathrm{nmol} / 1$ [48]. Oztekin and Oztekin, (2018) also noticed gender difference as female patients had lower serum vitamin $D$ levels when compared with male patients $(\mathrm{p}=0.002)^{[6]}$. This may be attributed to short duration to sun exposure in female due to indoor lifestyle and full coverage dressing, beside low dietary intake, increase body demand during pregnancy and breast feeding as well as excess adipose tissue of females resulting in greater fat storage of vitamin $\mathrm{D}^{[49]}$.

A significant inverse correlation exists in this study between serum levels of $25(\mathrm{OH}) \mathrm{D}$ and the severity of the RAU that represented by number of ulcers per attack and the frequency of recurrence. In a similar way, previous studies on vitamin D status in RAU-related syndromes such as pharyngitis, cervical adenitis (PFAPA) syndrome, periodic fever, aphthous stomatitis and Behcet disease, have revealed a positive correlation between low vitamin D level and disease activity ${ }^{[50,51]}$. On the other hand, Oztekin and Oztekin, (2018) and Nalbantog `lu and Nalbantog ${ }^{\jmath}$ lu, (2019) ${ }^{[6,43]}$ failed to determine any correlation between serum vitamin D levels and the severity of the RAU. This difference might be due to the different studied sample size or variation in the standardization through measurement of $25(\mathrm{OH}) \mathrm{D}$.

Several studies concluded that vitamin D is a significant factor in the etiology of T-cell mediated immune disorders ${ }^{[52-55]}$. Consequently, Vitamin D deficiency leads to immune system dysregulation which may play a role in the pathogenesis of RAU. Our findings in this study may also confirm this presumption.

\section{CONCLUSIONS}

In this study, significant relationship has been observed between vitamin D deficiency and the incidence of RAU. In addition there was a strong correlation between vitamin D deficiency and the severity of the disease, suggesting its role in the pathogenesis of RAU and the possibility of using vitamin $\mathrm{D}$ as adjunctive treatment in management of RAU.

\section{REFERENCES}

1. Akintoye SO, Greenberg MS. Recurrent aphthous stomatitis. Dent Clin North Am. 2014; 58: 281-297.

2. Bahramian A, Falsafi P, Abbasi T et al. Comparing Serum and Salivary Levels of Vitamin D in Patients with Recurrent Aphthous Stomatitis and Healthy Individuals. J Dent Shiraz Univ Med Sci., 2018 December; 19(4): 295-300.

3. Porter SR, Hegarty A, Kaliakatsou F, et al. Recurrent aphthous stomatitis. Clin Dermatol. 2000; 18: 569-78.

4. Bijelić B, Matić IZ, Besu I, Janković L, Juranić Z, Marušić $\mathrm{S}$, Andrejević S. Celiac disease-specific and inflammatory bowel disease-related antibodies in patients with recurrent aphthous stomatitis. Immunobiology. 2019 Jan; 224(1):7579. [PubMed]

5. Chiang CP, Yu-Fong Chang J, Wang YP, Wu YH, Wu YC, Sun A. Recurrent aphthous stomatitis - Etiology, serum autoantibodies, anemia, hematinic deficiencies, and management. J. Formos. Med. Assoc. 2018 Nov 14; [PubMed].

6. Öztekin A, Öztekin C. Vitamin D levels in patients with recurrent aphthous stomatitis. BMC Oral Health. 2018 Nov 09; 18(1):186. [PMC free article] [PubMed]. 
7. Brzeziński P, Wollina U, Espinoza-Benavides L, Chang P, Mohamed M, Geller SA. Dermatology eponyms-signlexicon (S). Part II. Our Dermatol Online. 2018; 9: 470-7.

8. Mortazavi H, Safi Y, Baharvand M, Rahmani S. Diagnostic features of common oral ulcerative lesions: an updated decision tree. Int J Dent. 2016; 2016:7278925.

9. Grimaux X, Leducq S, Goupille $\mathrm{P}$, Aubourg A, Miquelestorena-Standley E, Samimi M. [Aphthous mouth ulcers as an initial manifestation of sécukinumabinduced inflammatory bowel disease]. Ann Dermatol Venereol. 2018 Nov; 145(11):676-682. [PubMed].

10. Borilova Linhartova P, Janos J, Slezakova S, Bartova J, Petanova J, Kuklinek P, Fassmann A, Dusek L, Izakovicova Holla L. Recurrent aphthous stomatitis and gene variability in selected interleukins: a case-control study. Eur. J. Oral Sci. 2018 Dec; 126(6):485-492. [PubMed].

11. Brignardello-Petersen R. Patients who seek professional treatment of recurrent aphthous stomatitis probably have an increased risk of having head and neck cancer and other types of cancers. J Am Dent Assoc. 2019 Feb; 150(2):e24. [PubMed].

12. Rivera C: Recurrent Aphthus stomatitis. BIOMEDICAL REPORTS. 2019; 11: 47-50.

13. Reins RY, Hanlon S D, Magadi S, and McDermott A M. Effects of Topically Applied Vitamin D during Corneal Wound Healing. PLOS ONE I DOI: 10. 1371/ journal. pone.0152889April 1, 2016.

14. Gil A, Plaza-Diaz J and Mesa M. Vitamin D: Classic and Novel Actions. Ann Nutr Metab 2018; 72: 87-95.

15. Bouillon R, Carmeliet G, Verlinden L, van Etten E, Verstuyf A, Luderer HF, Lieben L, Mathieu C, Demay M: Vitamin D and human health: lessons from vitamin D receptor null mice. Endocr Rev 2008; 29: 726-776.

16. DeLuca HF: Evolution of our understanding of vitamin D. Nutr Rev 2008; 66(10 suppl 2):S73-S87.

17. Sassi F, Tamone C and D'Amelio P. Vitamin D: Nutrient, Hormone, and Immunomodulator. Nutrients. 2018; 10, 1656.

18. Demay MB. Mechanism of vitamin D receptor action. Ann N Y Acad Sci 2006; 68:204-213. [PubMed: 16831920].

19. Sun j. Vitamin D and mucosal immune function. Curr Opin Gastroenterol. November 2010; 26(6): 591-595.

20. Christakos S, Dhawan P, Verstuyf A, Verlinden L, Carmeliet G: Vitamin D: metabolism, molecular mechanism of action, and pleiotropic effects. Physiol Rev 2016; 96: 365-408.

21. Beyazit Y, Kocak E, Tanoglu A, Kekilli M. Oxidative stress might play a role in low serum vitamin D associated liver fibrosis among patients with autoimmune hepatitis. Dig Dis Sci 2015; 60: 1106-8.

22. Abramovitch S, Sharvit E, Weisman Y, et al. Vitamin D inhibits development of liver fibrosis in an animal model but cannot ameliorate established cirrhosis. Am J Physiol Gastrointest Liver Physiol 2015; 308: G112-20.

23. Holick MF. Vitamin D deficiency. N Engl J Med. 2007; 357: 266-81.

24. Kheiri B,Abdalla A, Osman M, et al. Vitamin D deficiency and risk of cardiovascular diseases: a narrative review. Clinical Hypertension. 2018; 24:9.

25. Gupta A, Sjoukes D and Richardsetal. "Relationship between serum vitamin D, disease severity, and airway remodeling in children with asthma," American Journal of Respiratory and Critical Care Medicine. 2011; vol.184, no. 12,pp. 1342-1349.

26. Zittermann A. Vitamin D in preventive medicine: are we ignoring the evidence? Br J Nutr. 2003; 89: 552-72.

27. Foss YJ. Vitamin D deficiency is the cause of common obesity. Med Hypotheses. 2009; 72: 314-21.

28. Kimlin MG. Geographic location and vitamin D synthesis. Mol Aspects Med. 2008; 29: 453-61.

29. Barnard K, Colón-emeric C. Extraskeletal effects of vitamin D in older adults: cardiovascular disease, mortality, mood, and cognition. Am J Geriatr Pharmacother. 2010; 8: 4-33.

30. Donovan DS, Papadopoulos A, Staron RB, Addesso V, Schulman L, Gregor CMC, Cosman F, Lindsay RL, Shane E. Bone mass and vitamin D deficiency in adults with advanced cystic fibrosis lung disease. Am J Respir Crit Care Med. 1998; 157: 1892-9.

31. Küçükazman M, Ata N, Dal K, Yeniova A, Kefeli A, Basyigit S, Aktas B, Akin K, Ağladığlu K, Üre Ö, Topal F, Nazliguil Y, Beyan E, Ertugrul D. The association of vitamin D deficiency with non-alcoholic fatty liver disease. Clin (Sao Paulo). 2014; 69: 542-6.

32. Bagan JV, Sanchis JM, Milian MA, et al. Recurrent aphthous stomatitis. A study of the clinical characteristics of lesions in 93 cases. Oral Pathol Med 1991; 20: 395-7. 
33. Adegoke S A, Braga JA P, Adekile AD and Figueiredo MS. The Association of Serum 25-Hydroxyvitamin D with Biomarkers of Hemolysisin Pediatric Patients with Sickle Cell Disease. Journal of Pediatric Hematology/Oncology. 2018; vol.40, no.2, pp. 159-162.

34. Holick M F, Binkley N C, Bischoff-Ferrari H A et al." Evaluation, treatment, and prevention of vitamin D deficiency: an endocrine society clinical practice guide line,'The Journal of Clinical Endocrinology \& Metabolism. 2011; vol. 96, no. 7, pp. 1911-1930.

35. Abdullah M.J. Prevalence of recurrent aphthous ulceration experience in patients attending Piramird dental speciality in Sulaimani City. J Clin Exp Dent 2013; 5(2), 89-94.

36. Patil S, Reddy S.N, Maheshwari S, Khandelwal S, Shruthi D, Doni B. Prevalence of recurrent aphthous ulceration in the Indian Population. J Clin Exp Dent 2014; 6 (1), 36-40

37. Shruthi H, Harini K, Vidya A, Subhas B, Shishir R.S. Prevalence of recurrent aphthous stomatitis: An institutional study. Cumhuriyet Dent J 2015; 18, 228-234.

38. Ship J.A, Chavez E.M, Doerr P.A, Henson B.S, Sarmadi M. Recurrent Aphthous Stomatitis. Quintessence Int 2000; 31 (2), 95-112.

39. Shijith M, Jincy T, Mol T.P, Vineet D.A, Sunila T, Vivek V. Frequency of Patients Presenting with Recurrent Aphthous Stomatitis: A Pilot Study. IOSR-JDMS 2014; 13 (1), 63-66.

40. Sumathi K, Shanthi B, Subha Palaneeswari M, Manjula Devi A.J. Significance of Ferritin in Recurrent Oral Ulceration. J Clin Diagn Res 2014;8(3):14-15.

41. Khabbazi, A., Ghorbanihaghjo, A., Fanood, F., Kolahi, S., Hajialiloo, M., \& Rashtchizadeh, N. A Comparative study of vitamin D serum levels in patients with recurrent aphthous stomatitis. The Egyptian Rheumatologist. 2014; 37(3),133-137.https ://doi.org/10.1016/j. ejr.2014.07.005.

42. Ali, N. S. M. Serum vitamin D levels in a sample of Iraqi female patients. Indian Journal of Public Health Research \& Development. 2019; 10(1), 919923. https://doi.org/ 10.5958/ 0976-5506. 2019.00178.5.

43. Nalbantoğlu B, and Nalbantoğlu, A. Vitamin D Levels in Children with Recurrent Aphthous Stomatitis. Ear, Nose \& Throat Journal. 2019; 1-4.

44. Tamer F and Avcı E. Decreased serum ferritin and vitamin D levels in Decreased serum ferritin and vitamin D levels in patients with recurrent aphthous stomatitis. Our Dermatol Online 3.2019.
45. Krawiecka, E., Slebioda, Z., Szponar, E., Kowalska, A., \& DorockaBobkowska, B. Vitamin D status in recurrent aphthous stomatitis. Postȩpy Dermatologii I Alergologii. 2017; 34(6), 612-617. https://doi. org/10.5114/pdia.2017.69683.

46. Hagenau T, Vest R, Gissel TN, Poulsen CS, Erlandsen M, Mosekilde L, Vestergaard P. Global vitamin D levels in relation to age, gender, skin pigmentation and latitude: an ecologic meta-regression analysis. Osteoporos Int. 2009; 20:133-140.

47. Arabi A, El Rassi R, El-Hajj Fuleihan G. Hypovitaminosis $\mathrm{D}$ in Developing CountriesPrevalence, Risk Factors and Outcomes. Nat Rev Endocrinol 2010; 6(10): 550-61. 2.

48. Ardawi MS, Qari MH, Rouzi AA, Maimani AA, Raddadi RM. Vitamin D status in relation to obesity, bone mineral density, bone turnover markers and vitamin D receptor genotypes in healthy Saudi pre- and postmenopausal women. Osteoporos Int 2011; 22:463-475.

49. Dijkstra SH, van BA, Janssen JW, de Vleeschouwer LH, Huysman WA, van den Akker EL. High prevalence of vitamin D deficiency in newborn infants of high-risk mothers. Arch Dis Child 2007; 92:750-753.

50. Stagi S, Bertini F, Rigante D, Falcini F. Vitamin D levels and effects of vitamin D replacement in children with periodic fever, aphthous stomatitis, pharyngitis, and cervical adenitis (PFAPA) syndrome. Int J Pediatr Otorhinolaryngol. 2014; 78(6):964-968.

51. Ganeb SS, Sabry HH, El-Assal MM, et al. Vitamin D levels in patients with Behc, et's disease: significance and impact on disease measures. Egypt Rheumatol. 2013; 35(3):151-157.

52. Munger KL, Levin LI, Hollis BW, Howard NS, Ascherio A. Serum 25-hydroxyvitamin D levels and risk of multiple sclerosis. JAMA. 2006; 296, 2832-8.

53. Cigolini M, Iagulli MP, Miconi V, Galiotto M, Lombardi S, Targher G. Serum 25-hydroxyvitamin D3 concentrations and prevalence of cardiovascular disease among type 2 diabetic patients. Diabetes Care. 2006; 29, 722-4.

54. Cutolo M, Otsa K, Laas K et al. Circannual vitamin d serum levels and disease activity in rheumatoid arthritis: Northern versus Southern Europe. Clin Exp Rheumatol. 2006; 24, 702-4.

55. Pappa HM, Grand RJ, Gordon CM. Report on the vitamin $\mathrm{D}$ status of adult and pediatric patients with inflammatory bowel disease and its significance for bone health and disease. Inflamm Bowel Dis. 2006; 12, 1162-74. 